\title{
Protein patterns of human uterine flushings collected at various stages of the menstrual cycle
}

\author{
J. B. Maathuis* and R. J. Aitken \\ M.R.C. Unit of Reproductive Biology, 23 Chalmers Street, Edinburgh EH9 3EW, U.K.
}

\begin{abstract}
Summary. Uterine flushings and plasma collected from normal, parous women at various stages of the menstrual cycle were subjected to gel electrophoresis. The protein profiles of the flushings differed in many instances from the plasma pattern by the presence of between one and eleven non-plasma proteins. The distribution of the major non-plasma proteins during the menstrual cycle was not statistically significant but that of a pretransferrin, observed in uterine flushings and in peritoneal fuid, was significant. However, the appearance of this protein band could not be related to a particular phase of the cycle, and hence to a specific hormonal condition.
\end{abstract}

\section{Introduction}

The initiation of implantation is associated with the presence of characteristic non-plasma proteins in the uterine lumen of marsupials (Renfree, 1973), lagomorphs (Beier, 1968; Krishnan \& Daniel, 1967), rodents (Aitken, 1977a; Surani, 1976) and artiodactyls (Aitken, 1974; Roberts, Parker \& Symonds, 1976a; Squire, Bazer \& Murray, 1972). Several attempts have been made to detect similar proteins in human uterine fluid during ovulatory cycles in which conception does not occur (Beier, Petry \& Kühnel, 1970; Bernstein, Aladjem \& Chen, 1971; Shirai, Iizuka \& Notake, 1972; Wolf \& Mastroianni, 1975; Roberts, Parker \& Henderson, 1976b). These reports have rarely excluded the possibility of contamination of the uterine sample by semen, cervical mucus, tubal fluid and blood. Fluids from different parts of the female reproductive tract are bound to mix in vivo, at least at certain stages of the oestrous or menstrual cycle. However, it is important that studies on the luminal environment in a particular part of the genital tract exclude contamination by fluids originating in other areas. This is the more compelling when proteins are analysed, because seminal plasma (Hermann \& Hermann, 1969; Kirchner \& Schroer, 1976), cervical mucus (Moghissi, 1973; Roberts et al., 1976a) and tubal fluid (Goswami \& Feigelson, 1974) contain antigens undetectable in plasma.

The purpose of this study was to assess qualitatively the protein composition of uterine flushings obtained with an improved flushing technique which virtually excludes contamination with cervical mucus and tubal fluid.

\section{Materials and Methods}

Biological fluids. The selection criteria for the subjects in this study, the indices used to assess the phase of the menstrual cycle (early (EP), mid-(MP) and late (LP) proliferative and early (ES), mid-(MS) and late (LS) secretory) and the procedures employed to obtain uterine flushings $(n=52)$ have been described previously (Maathuis \& Aitken, 1978). The amount of 'uterine' protein was calculated by subtracting the amount of contaminating plasma protein from the quantity of total protein in each sample (Maathuis \& Aitken, 1978). Peritoneal fluid was also aspirated from each subject (Maathuis, Van Look \& Michie, 1978).

Gel electrophoresis. Gel electrophoresis was carried out at $\mathrm{pH} 8.9$ on polyacrylamide columns by the method of Davis (1964). Because the relative amounts of contaminating protein and 'uterine' protein were different in each uterine sample a known volume $(100 \mu 1)$ of the flushings rather than a

* Present address: Department of Obstetrics and Gynaecology, Leiden University Hospital, Rijnsburgerweg 10, Leiden, The Netherlands. 
known amount of protein was applied to each column. For most samples this volume contained between 100 and $200 \mu \mathrm{g}$ protein. Samples of plasma and peritoneal fluid from the same subject, diluted in Tris-glycine buffer (Davis, 1964) and containing about $150 \mu \mathrm{g}$ protein, were processed at the same time. All samples were mixed with a solution of bromophenol blue and sucrose in water, and these compounds served as a marker. Electrophoresis was continued until this marker band had nearly reached the end of the column. In addition, plasma from each subject was diluted in $0.9 \%(\mathrm{w} / \mathrm{v}) \mathrm{NaCl}$ solution to a concentration of protein equal to that of the contaminating plasma protein of the corresponding uterine flushings and a sample of $100 \mu \mathrm{l}$ of this solution was subjected to electrophoresis. This approach served two purposes: (1) to ensure that protein patterns in uterine flushings which differed from the plasma protein profile could not have resulted from the dilution of plasma proteins in the flushing medium, and (2) to visualize the contribution from the contaminating plasma protein to the overall protein pattern. Proteins were stained with Coomassie brilliant blue $(0.25 \%, w / v)$, amido black $(0 \cdot 1 \%, w / v)$ and methanol $(20 \%, v / v)$ in $7 \%(v / v)$ acetic acid. Hand drawings were made from all gels. The electrophoretic mobilities ( $R a$ value; $R a$ albumin $=1 \cdot 0$ ) were calculated in relation to the middle of the albumin band (Peplow, Breed, Jones \& Eckstein, 1973). Protein bands were classified as pre-albumins $(R a>1 \cdot 0)$, post-albumins $(R a 1 \cdot 0-0.66)$, pre-transferrins ( $R a 0.65-0.55)$ and post-transferrins ( $R a 0.53-0)$. The mean ( $($ s.d.) $R a$ value of transferrin measured in 20 consecutive samples of plasma and uterine flushings analysed in 6 different electrophoretic runs was $0.54 \pm 0.02$ and $0.55 \pm 0.02$, respectively. Protein bands were named non-plasma protein bands when their electrophoretic mobility did not correspond to any protein band in plasma, or when the relative concentration in the uterine flushings was markedly greater, suggesting local production but not implying antigenic difference from plasma proteins (Schultze \& Heremans, 1966).

Statistical analysis. The distribution of the non-plasma protein bands over the various phases of the menstrual cycle was analysed with the $\chi^{2}$ test (Snedecor \& Cochran, 1967).

\section{Results}

\section{Protein pattern of plasma}

Electropherograms of plasma showed between 18 and 24 separate bands. Constant features, apart from albumin and transferrin, were 2 pre-albumin (one sharp band with an $R a$ value of 1.41 and a fuzzy band not reaching the edges of the gel with an $R a$ value of $1 \cdot 14)$ and 3 post-albumin $(R a 0 \cdot 81$, 0.76 and 0.70$)$ bands. In the pre-transferrin region 1 faint band $(R a 0.64)$ was seen in the majority of gels. In the immediate post-transferrin area 3 and occasionally 4 bands $(R a 0 \cdot 46,0 \cdot 39,0 \cdot 35$ and $0 \cdot 30$ ) were observed, whereas between 7 and 13 bands were seen against the darker stained background of the gamma globulin region ( $R a 0 \cdot 29-0$ ). The stage of the menstrual cycle had no influence on the plasma protein profile.

\section{Protein pattern of uterine flushings}

Two samples had too low a concentration of protein to provide gels of sufficient quality (1 ES, $1 \mathrm{LS})$. In addition to the protein bands seen in plasma and occasional traces of haemoglobin ( $\mathrm{Hb}$; $R a 0.64)$, detectable in 11 out of 50 gels, a maximum of 11 non-plasma protein bands were observed. Five of these were faint pre-albumins $(R a 1 \cdot 54,1.48,1.44,1.28$ and 1.24), two were post-albumins $(R a 0.84$ and 0.79$)$, one was a pre-transferrin $(R a 0.59)$ and three were post-transferrins $(R a 0.46,0.41$ and 0.32 ). Pictures of representative gels and diagrams illustrating the observed non-plasma protein bands and the corresponding saline-diluted plasma electropherograms are shown in Pl. 1, Figs 1-3.

\section{Protein pattern of peritoneal fluid}

Electropherograms of peritoneal fluid differed from the corresponding plasma sample by weaker staining in the gamma globulin area. A non-plasma protein band with an $R a$ value of 0.59 (see Pl. 1 , Fig. 4) was seen in 11 out of 50 gels. 
PLATE 1
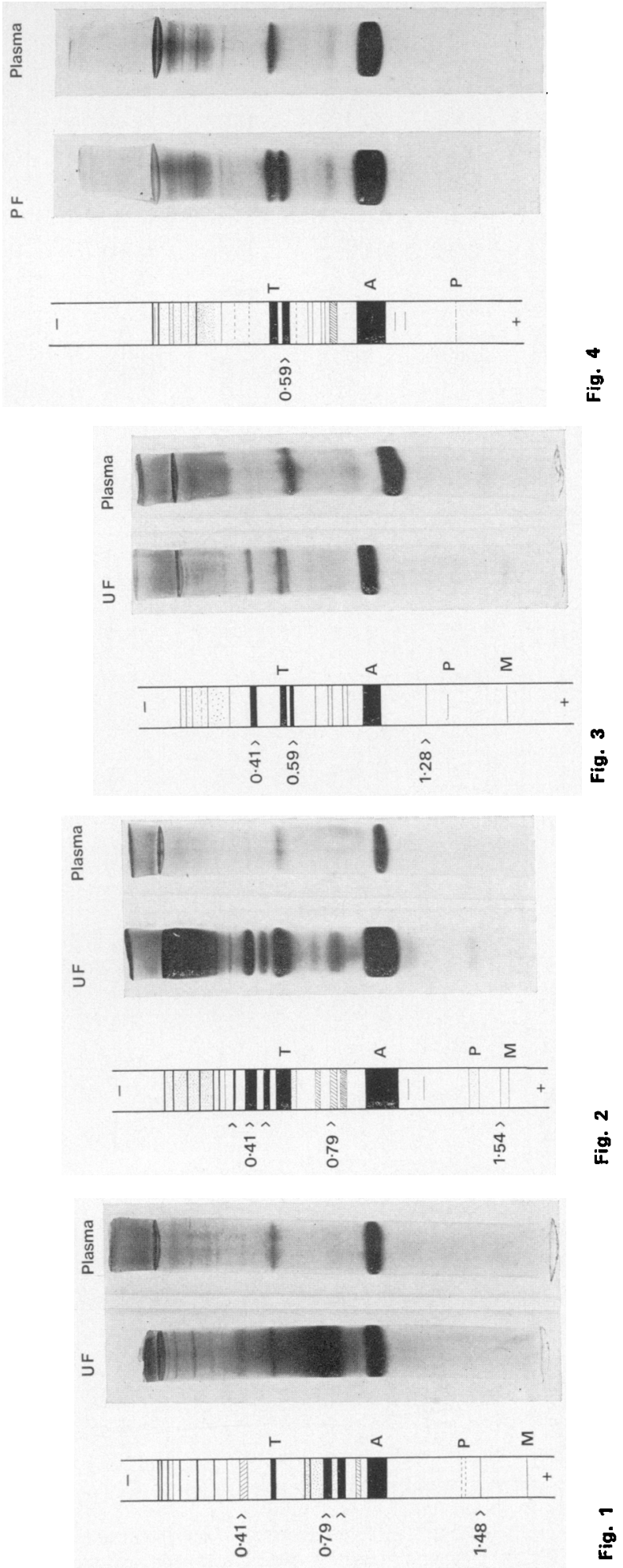
PLATE 2
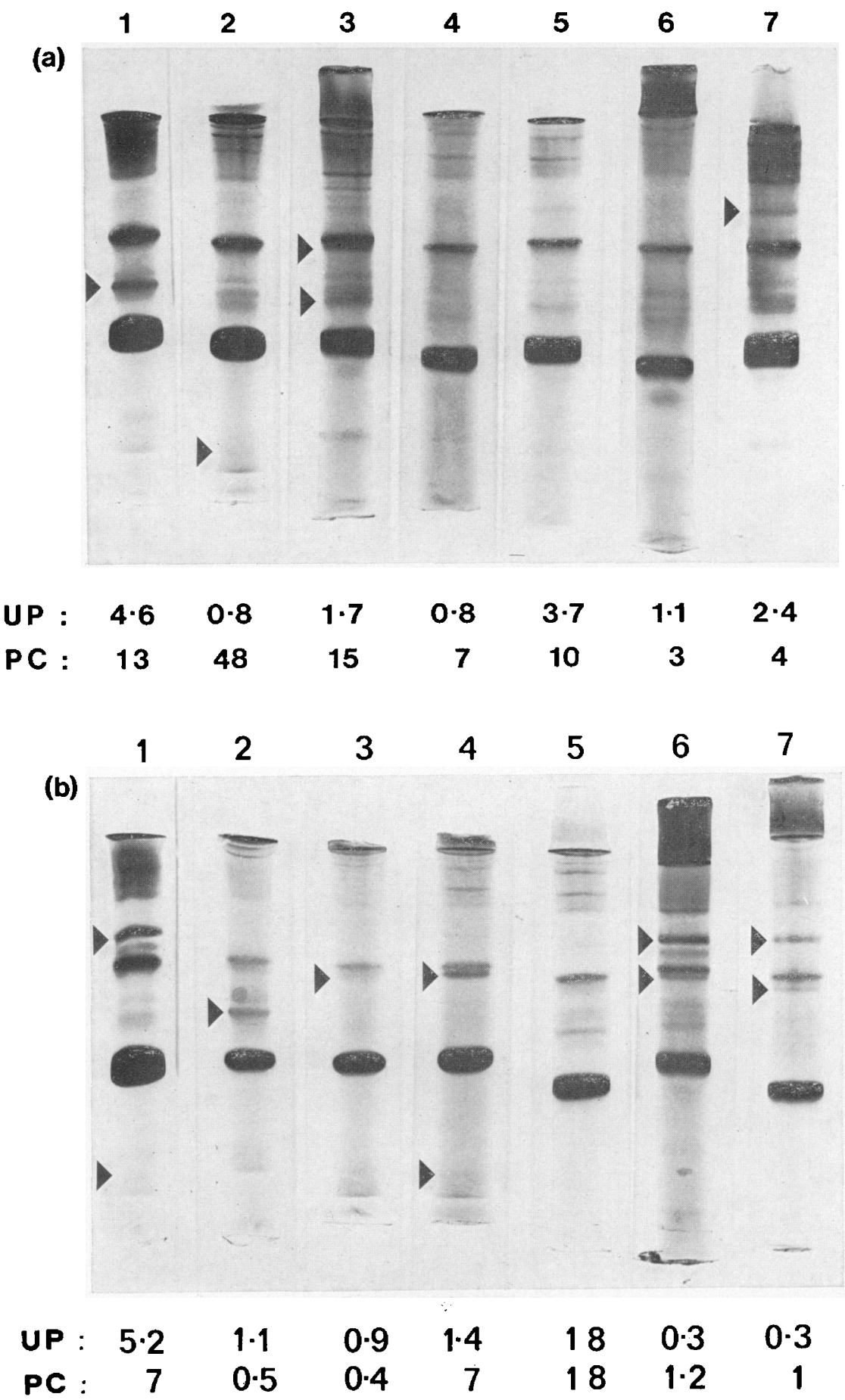

Fig. 5. Electrophoretic patterns in polyacrylamide gels (see Plate 1) of human uterine flushings which were different from those in plasma and from each other in samples collected during (a) the late proliferative stage and (b) the mid-secretory stage. The concentrations of uterine protein (UP; mg/ml flushing) and the plasma contamination (PC; $\mu \mathrm{l}$ plasma $/ \mathrm{ml}$ flushing) are indicated for each sample. The arrow indicates nonplasma protein bands. 


\section{Distribution of non-plasma proteins in uterine fushings during the menstrual cycle}

The occurrence of the major non-plasma protein bands in relation to the stage of the menstrual cycle is summarized in Table 1.

Table 1. The occurrence of non-plasma proteins in uterine flushings (UF) and in peritoneal fluid (PF) from women at different stages of the menstrual cycle (no. of samples in parentheses)

\begin{tabular}{|c|c|c|c|c|c|c|c|c|}
\hline \multirow[b]{3}{*}{$R a$ value } & \multirow[b]{3}{*}{$\begin{array}{l}\text { Biological } \\
\text { fluid }\end{array}$} & \multicolumn{6}{|c|}{ Phase of the menstrual cycle } & \multirow[b]{3}{*}{$\chi_{5}^{2}$} \\
\hline & & \multicolumn{3}{|c|}{ Proliferative } & \multicolumn{3}{|c|}{ Secretory } & \\
\hline & & $\begin{array}{c}\text { Early } \\
\text { (5) }\end{array}$ & $\begin{array}{l}\text { Mid- } \\
\text { (13) }\end{array}$ & $\begin{array}{l}\text { Late } \\
\text { (11) }\end{array}$ & $\begin{array}{c}\text { Early } \\
(5)\end{array}$ & $\begin{array}{l}\text { Mid- } \\
\text { (11) }\end{array}$ & $\begin{array}{c}\text { Late } \\
(5)\end{array}$ & \\
\hline \multirow{4}{*}{$\begin{array}{l}0.41 \\
0.59\end{array}$} & UF & 2 & 5 & 4 & 3 & 6 & 3 & 1.894 \\
\hline & UF & 2 & 10 & 6 & 2 & 8 & 3 & $4 \cdot 088$ \\
\hline & PF & 0 & 3 & 1 & 1 & 2 & 4 & $12 \cdot 394^{*}$ \\
\hline & $U F+P F$ & 0 & 3 & 1 & 1 & 0 & 3 & $11 \cdot 185^{*}$ \\
\hline 0.79 & UF & 1 & 2 & 1 & 2 & 1 & 3 & 8.059 \\
\hline $1 \cdot 28$ & UF & 0 & 2 & 4 & 1 & 2 & 2 & $4 \cdot 113$ \\
\hline
\end{tabular}

* The distribution of the non-plasma pre-transferrin protein of $R a 0.59$ in these fluids was significantly different, $P<0.05$.

Early proliferative stage. One sample, collected on the last day of menstruation, contained heavy bands with $R a$ values of 0.84 and 0.79 , in addition to bands with $R a$ values of 1.41 and 0.41 (Pl. 1 , Fig. 1). One gel was indistinguishable from the corresponding plasma sample. The 3 remaining gels showed weak background staining in the gamma globulin area. Two of these gels contained 2 nonplasma proteins ( $R a 1 \cdot 54,1.44$ and $R a 0.59,0.41$ respectively), one contained the band with $R a 0.59$.

Mid-proliferative stage. Of the 10 samples in this group containing the band with $R a$ value 0.59 , 1 showed darkly stained bands with $R a$ values 0.79 and $0.41,3$ gels contained the band with $R a$ value 0.41 and 1 gel showed the band with $R a$ value $1 \cdot 28$. The background staining in the gamma globulin region was weak in most of the samples.

Late proliferative stage. Of the 11 gels in this group 7 profiles different from those of plasma and from each other were observed. These gels, shown in Pl. 2, Fig. 5(a), did not exhibit constant features, apart from a reasonably prominent background staining in the gamma globulin region.

Early secretory stage. Three of the 5 gels in this group showed the band with $R a$ value $0.41,1$ gel in combination with the band with $R a$ value $0.79,1$ gel in combination with 2 bands $(R a 1.48$ and 0.79 ) and 1 gel together with the band with $R a$ value $0 \cdot 59$.

\section{EXPLANATION OF PLATE 1}

Gel electrophoresis, on columns of $7 \%$ polyacrylamide, pH 8.9 , of (Figs 1-3) uterine flushings (UF) and paired saline-diluted plasma (see 'Materials and Methods"), and (Fig. 4) peritoneal fluid (PF, see Table 1) and plasma samples from women at different stages of the menstrual cycle. The electrophoretic mobilities of prominent non-plasma proteins are shown. $M=$ the marker band, $P=$ pre-albumin, $A=$ albumin and $\mathbf{T}=$ transferrin.

Fig. 1. Samples collected during the early proliferative stage. Note the heavily staining bands with $R a$ values of 0.84 and 0.79 .

Fig. 2. Samples collected during the early secretory stage. Note the prominent band with $R a$ value of $0 \cdot 41$. Fig. 3. Samples collected during the mid-secretory stage. Note the presence of a non-plasma pre-transferrin with $R a$ value 0.59 .

Fig. 4. Samples collected during the early secretory stage. Note the presence of a very prominent nonplasma pre-transferrin with the same $R a$ value as the pre-transferrin in uterine flushings shown in Fig. 3. 
Mid-secretory stage. Seven of the profiles in the 11 gels were different from those of plasma and from each other (Pl. 2, Fig. 5b).

Late secretory stage. The gel from one subject whose endometrial biopsy showed evidence of the start of menstruation contained very prominent bands with $R a$ values 0.79 and 0.70 .

\section{Discussion}

The limited number of studies on proteins of human uterine flushings agree in only one respect: all report the absence of a quantitatively dominant protein at any phase of the sterile cycle (Beier et al., 1970; Roberts et al., 1976b; Shirai et al., 1972; Wolf \& Mastroianni, 1975). This is confirmed by our study. The number of non-plasma protein bands reported, however, differs in each study, as does the electrophoretic mobility of the observed proteins. Pre-albumins were not reported by Shirai et al. (1972) and Wolf \& Mastroianni (1975). Roberts et al. (1976b) detected two pre-albumins, the fastest of which may correspond to one ( $R a$ value $1 \cdot 24$ ) of the 5 pre-albumins reported here. The presence of post-albumins in the uterine flushings as shown in this study and as reported by Shirai et al. (1972), Daniel (1973) and Wolf \& Mastroianni (1975) has led to speculations that one of these proteins may be analogous to uteroglobin (Beier, 1968) or blastokinin (Krishnan \& Daniel, 1967). However, as pointed out by Beier \& Beier-Hellwig (1973) and Roberts et al. (1976b), the post-albumins reported by Shirai $e t$ al. (1972) are probably related to the heavy contamination with blood resulting from their technique. Wolf \& Mastroianni (1975) failed to obtain immunological evidence that the post-albumins mentioned in their study are of uterine origin. Daniel (1973) detected a post-albumin, in a secretory-phase uterine flushing, which migrated like blastokinin and provided evidence that this flushing contained an antigen-not necessarily the one visualized on acrylamide - which crossreacted with anti-blastokinin. He suggested that the synthesis of this protein was under hormonal control. This is not supported by our results because we saw similar protein bands at all stages of the cycle (Table $1 ;$ Pl. 2, Fig. 5). The relative concentration of the post-albumins with $R a$ values of 0.84 and 0.79 was greatest in samples collected from subjects who had either just started or just finished menstruating. In addition, immunodiffusion studies (Ouchterlony, 1968) did not reveal crossreactivity between an antiserum raised against blastokinin in goats (a gift from $\mathrm{Dr} D$. W. Bullock) and samples containing prominent post-albumins or samples collected during the MS phase (R. J. Aitken \& J. B. Maathuis, unpublished). The same antiserum, which is not completely monospecific (D. W. Bullock, personal communication), was used by Noske \& Feigelson (1976), who similarly failed to detect cross-reactivity with uterine flushings on immunodiffusion plates. However, these authors reported positive results when using immunoelectrophoresis and radial immunodiffusion, without giving an explanation for this discrepancy:

The protein with $R a$ value of $0 \cdot 59$, frequently seen in uterine flushings, was not detected in plasma, but a prominent band with the same $R a$ value was repeatedly observed in samples of peritoneal fluid (see Pl. 1, Fig. 4). The appearance of this protein either in the uterine flushing only or in peritoneal fluid only (see Table 1) would suggest that it originates from at least two different areas. On the other hand, the simultaneous occurrence of this protein in uterine flushing and peritoneal fluid in some of the subjects (Table 1) may indicate some exchange of fluid between the uterine and peritoneal cavities.

The post-transferrin with $R a$ value of 0.41 is probably similar to the post-transferrin found in human tubal fluid (Beier \& Beier-Hellwig, 1973) and in uterine flushings (Wolf \& Mastroianni, 1975; Roberts et al., 1976b). Unlike our findings (Table 1), Roberts et al. (1976b) reported that this protein varied in intensity with the stage of the menstrual cycle, but their patient classification according to the day of the cycle based on menstrual history and endometrial biopsy may not be sufficiently accurate (Maathuis et al., 1978). Again unlike Roberts et al. (1976b), we did not see non-plasma protein bands in the gamma globulin region. The more heavily stained background in this area in samples collected during the late proliferative period agrees with the quantitative results obtained by Maathuis \& Aitken (1978) for this stage of the cycle.

The occurrence of non-plasma protein bands does not seem to be related to the 'uterine' protein content, the extent of its plasma contamination (see Pl. 2, Fig. 5), or to the stage of the menstrual 
cycle. These bands may represent modified plasma proteins, secreted 'uterine' proteins or proteins accidentally released from endometrial cells. This random appearance contrasts with results from other species, in many of which a defined pattern of endometrial secretory activity may be found at the time of implantation (Aitken, 1977b). The appearance of characteristic proteins within the uterine lumen at the time of implantation in some mammals has led to much speculation about the physiological significance of these 'uterine-specific' proteins, but most of the suggestions still need to be substantiated. The embryotrophic properties of blastokinin (Krishnan \& Daniel, 1967) have not yet been confirmed (Maurer \& Beier, 1976). Furthermore, because blastokinin (uteroglobin) has been detected immunologically in other organs, e.g. the lung (Noske \& Feigelson, 1976; Daniel \& Crowder, 1977) and in fluids from the male genital tract of the rabbit and man (Beier, Bohn \& Muller, 1976; Kirchner \& Schroer, 1976; Noske \& Feigelson, 1976), this protein can no longer be considered to be 'uterine-specific'.

As yet, no clear explanation has been given of how the suggested stimulatory actions of "uterinespecific' proteins in various species are to be reconciled with the results from studies in vitro and transplantation experiments. Relatively simple media can meet the requirements of the preimplantation stage embryo of all species studied, including man (for review see Brinster, 1973). Neither the endocrine state nor the sex of recipient appear to be important for blastocyst metabolism and growth in intraperitoneal (Bryson, 1964) or other extra-uterine sites (Kirby, 1963). These observations make it unlikely that stimulatory uterine factors are essential for implantation. Experiments on asynchronous egg transfer, however, have shown that the uterus of the mouse, rat and rabbit (for review see Adams, 1967) as a whole exerts a negative influence on the fate of morulae or blastocysts except near the time of implantation. It appears from this experimental evidence that the uterus is exceptional in these species, not because it possesses factors stimulating the blastocyst, but because of its property to exhibit only a limited period of hormonally controlled receptivity towards a potentially aggressive invader.

The present study shows that (1) the distribution of the non-plasma protein bands in uterine flushings collected during cycles in which conception does not occur cannot form the basis for a hypothesis about a possible physiological role of these proteins, and (2) distinct dissimilarities between the electrophoretic profiles of two different biological fluids collected from one subject are not necessarily related to the endocrine state of that subject. The first conclusion does not exclude the possibility that different results may be obtained by study of flushings collected from human uteri containing blastocysts. It has been shown, for example, that blastocysts can actively stimulate the release of endometrial secretions in the mouse (Aitken, 1977b) and wallaby (Renfree, 1973).

We thank Dr D. W. Bullock, Houston, Texas, for the antiserum to blastokinin; Professor D. T. Baird and Professor R. V. Short for encouragement and advice; and the World Health Organization and Medical Research Council for a Research Training Grant (J.B.M.) and a Postdoctoral Fellowship (R.J.A.).

\section{References}

ADams, C.E. (1967) Ovarian control of early embryonic development within the uterus. In Reproduction in the Female Mammal, pp. 532-546. Eds G. E. Lamming \& E. C. Amoroso. Butterworths, London.

Aitken, R.J. (1974) Delayed implantation in the roe deer (Capreolus capreolus). J. Reprod. Fert. 39, 225-233.

AITKEN, R.J. (1977a) Changes in the protein content of mouse uterine flushings during normal pregnancy and delayed implantation, and after ovariectomy and oestradiol administration. J. Reprod. Fert. 50, 29-36.

Aitken, R.J. (1977b) Embryonic diapause. In Development in Mammals, pp. 307-359. Ed. M. H. Johnson.
Elsevier/North Holland Biomedical Press, Amsterdam.

BeleR, H.M. (1968) Uteroglobin: a hormone-sensitive endometrial protein involved in blastocyst development. Biochim. biophys. Acta 160, 289-291.

Beier, H.M. \& Beier-Hellwig, K. (1973) Specific secretory protein of the female genital tract. Acta endocr., Copenh., Suppl. 180, 404-423.

Beier, H.M., Bohn, H.R. \& Muller, W. (1976) Uteroglobin-like antigen in the male genital tract secretions. Cell Tiss. Res. 165, 1-12.

Beier, H.M., Petry, G. \& Kühnel, W. (1970) Endometrial secretion and early mammalian development. 
In Mammalian Reproduction, pp. 264-285. Eds H. Gibian \& E. J. Plotz. Springer, Berlin.

Bernstein, G.S., Aladjem, F. \& Chen, S. (1971) Proteins in human endometrial washings-A preliminary report. Fert. Steril. 22, 722-726.

BRINSTER, R.L. (1973) Nutrition and metabolism of the ovum, zygote, and blastocyst. In Handbook of Physiology, Section 7, Volume II, Part 2, pp. 165-185. Eds R. O. Greep \& E. B. Astwood. Williams \& Wilkins, Baltimore.

Bryson, D.L. (1964) Development of mouse eggs in diffusion chambers. Science, N.Y. 144, 1351-1353.

DANiEL, J.C. (1973) A blastokinin-like component from the human uterus. Fert. Steril. 24, 326-328.

Daniel, J.C. \& Crowder, J.W. (1977) Lung blastokinin during pregnancy in the rabbit. $J$. Reprod. Fert. 50 , 145-146.

Davis, J.B. (1964) Disc electrophoresis. II. Method and application to human serum proteins. Ann. N.Y. Acad. Sci. 121, 404-427.

Goswami, A. \& Feigelson, M. (1974) Differential regulation of a lower-molecular-weight protein in oviductal and uterine fluids by ovarian hormones. Endocrinology 95, 669-675.

Mermann, W.P. \& HermanN, G. (1969) Chromatographische Fraktionierung und immunologische Analyse von menslichem Spermaplasma. Arch. Klin. Exp. Dermatol. 234, 100-116.

KIRBY, D.R.S. (1963) Development of the mouse blastocyst transplanted to the spleen. J. Reprod. Fert. 5, 1-12.

Kirchner, C. \& Schroer, H.G. (1976) Uterine secretionlike proteins in the seminal plasma of the rabbit. J. Reprod. Fert. 47, 325-330.

KRISHNAN, R.S. \& DANiEL, J.C. (1967) 'Blastokinin': inducer and regulator of blastocyst development in the rabbit uterus. Science, N. Y. 158, 490-492.

MaAThuis, J.B. \& Aitken, R.J. (1978) Cyclic variation in concentrations of protein and hexose in human uterine flushings collected by an improved technique. J. Reprod. Fert. 52, 289-295.

MaAthuis, J.B., Van Look, P.F.A. \& Michie, E.A. (1978) Changes in volume, total protein and ovarian steroid concentrations of peritoneal fluid throughout the human menstrual cycle. $J$. Endocr. 76, 123-133.

Maurer, R.R. \& Beier, H.M. (1976) Uterine proteins and development in vitro of rabbit preimplantation embryos. J. Reprod. Fert. 48, 33-41.

Moghissi, K.S. (1973) Composition and function of cervical secretion. In Handbook of Physiology, Section 7, Volume II, Part 2, pp. 25-48. Eds R. O. Greep \& E. B. Astwood. Williams \& Wilkins, Baltimore.

Noske, I.G. \& Feigelson, M. (1976) Immunological evidence of uteroglobin (blastokinin) in the male reproductive tract and in nonreproductive ductal tissues and their secretions. Biol. Reprod. 15, 704-713.

OUCHTERLONY, O. (1968) Handbook of Immunodiffusion and Immunoelectrophoresis. Ann Arbor Science Publishers, Ann Arbor, Michigan.

Peplow, V., Breed, W.G., Jones, C.M.J. \& Eckstein, P. (1973) Studies on uterine flushings in the baboon. I. Method of collection, cellular composition, and protein electrophoretic profiles in animals with and without intrauterine contraceptive devices. Am. J. Obstet. Gynec. 116, 771-779.

Renfree, M.B. (1973) Proteins in the uterine secretions of the marsupial, Macropus eugenii. Devl Biol. 32, 41-49.

Roberts, G.P., PARker, J.M. \& Symonds, H.W. (1976a) Macromolecular components of genital tract fluids from the sheep. $J$. Reprod. Fert. 48, 99-107.

Roberts, G.P., Parker, J.M. \& Henderson, S.R. (1976b) Proteins in human uterine fluid. J. Reprod. Fert. 48, 153-157.

Schultze, H.E. \& Heremans, J.F. (1966) Molecular Biology of Human Proteins, Volume I, p. 655. Elsevier, Amsterdam.

Shirai, E., Irzuka, R. \& Notake, Y. (1972) Analysis of human uterine fiuid protein. Fert. Steril. 23, 522-528.

Snedecor, G.W. \& Cochran, W.G. (1967) Statistical Methods, 6th edn, p. 235. Iowa State University Press, Ames, Iowa.

Squire, G.D., Bazer, F.W. \& Murray, F.A. (1972) Electrophoretic patterns of porcine uterine protein secretions during the estrous cycle. Biol. Reprod. 7, 321-325.

SURANI, M.A.H. (1976) Uterine luminal proteins at the time of implantation in rats. J. Reprod. Fert. 48, 141-145.

Wolf, D.P. \& Mastroianni, L. (1975) Protein composition of human uterine fluid. Fert. Steril. 26, 240-247.

Received 30 November 1977 